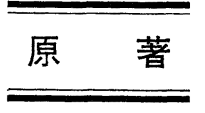

\title{
子宮癌細胞診自動化のための検体前処理法の検討 (補遺)
}

\author{
国立がんセンター臨床検査部細胞検查室 ${ }^{1)}$, 国立横浜病院研究検查科2) \\ 上井 良夫" ${ }^{1)}$ 塩沢 勇治 ${ }^{2}$
}

\begin{abstract}
腺癌細胞は扁平上皮癌細胞よりも分散しがたく, 子宮癌の細胞診自動化にあたり腺癌の存在を考 慮すると, その分散法を検討する要がある. そこで, 先に報告したわれわれの方法4)を改変して, ヒト腺癌 55 症例の細胞分散法を検討した．腺癌の組織带型を乳頭状, 非乳頭状, 硬癌の 3 型に, 細 胞分化度を高度, 中等度, 低分化に, 細胞分散度を優, 良, 可の 3 段階に分けると, 分散良好 (優) のものは乳頭状癌 (11 例) では 4 例 (36\%), 非乳頭状癌 (41 例) では 31 例 (76\%), 硬癌 (3 例) で は 2 例 $(67 \%)$ となり, 高分化癌 (17 例) では 9 例 (53\%), 中等度分化癌 (22 例) では 14 例 (64 \%), 低分化癌 (16 例) では 14 例 (88\%) となった. 本法は検体を高速で攪拌し細胞を分散する方 法であるが, 細胞質が保存されているものは 46 例（84\%）あった.

次に自動細胞診断の誤陽性の原因となる好中球を除去するために, streptolysin-O を用いて腟ス ミアに好中球の多い 29 症例について検討したところ, 有効例は 23 例 (80\%), 無効例は 6 例 $(20 \%)$ となった.
\end{abstract}

Key words : Cell dispersion —-Adenocarcinoma - Leukocyte elimination-Cytology automation

\section{I.はじめに}

われわれは前報) において，子宮癌細胞診自動化のた めの検体前処理法として, サコマノ法による細胞分散法 を報告した。本法は扁平上皮癌を対象としたものであ り, 腺癌細胞は扁平上皮癌細胞よりも細胞結合が強く分 散しがたいので, 今回は腺癌細胞の分散法を検討した. さらに自動診断の際，誤陽性の原因となる好中球を除去 するために，今回は streptolysin-O による方法を試み た.

\footnotetext{
A specimen preparation technique for automated cervical cancer prescreening - Supplementary report-

Yoshio UEI, M.D., F.I.A.C.

Cytology Section of National Cancer Center Hospital, Tokyo

Yuji SHIOSAWA, M.T., C.T., I.A.C.

Clinical Laboratory of Yokohama National Hospital

論文別刷請求先 104 東京都中央区築地 5 の 1 の 1 国立が

んセンター 上井良夫

昭和 61 年 9 月 4 日受付

昭和 62 年 1 月 16 日受理
}

\section{II. 腺癌細胞の分散}

子宮頸部と体部腺癌細胞の分散法を確立するために, 次のような基礎実験を行った。

1. 材 料

(1) ルチンの腟スミア中にきわめて多数の癌細胞を認 めた子宮体癌および頸部腺癌症例の生食による胵洗浄液 あるいは後者の綿棒による直接擦過物 ( 6 例).

(2)きわめて多数の腺癌細胞（原発を問わず）を認め た胸腹水 ( 3 例).

（3）外科的に剔出された子宮体癌組織のキュレットに よる擦過物 (6 例).

(4) 手術扔よび剖検により得られた腺癌組織（原発を 問わず）のキュレットによる擦過物あるいはメスで一辺 が 1〜2 mm に細切したもの (43 例).

胵洗浄液と胸腹水は, 遠沈 (1,500 rpm, 5 分) 後の沈 渣を一子宮顓部の擦過綿球は生食水に入れて用手的に細 胞をしぼり出したものを同様に遠沈した沈渣を一, キュ レットによる擦過物とメスによる細切片は直接， $2 \%$ カ 


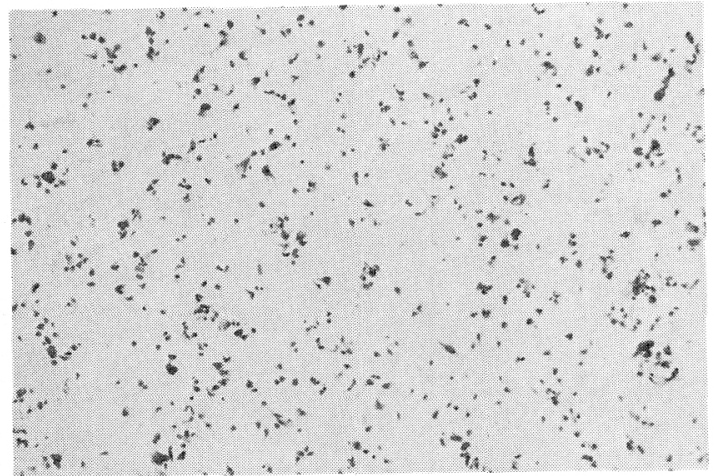

図１＼cjkstart細胞分散度 “優” の標本

(乳腺の充実腺管癌, Pap. 染色, × 25)

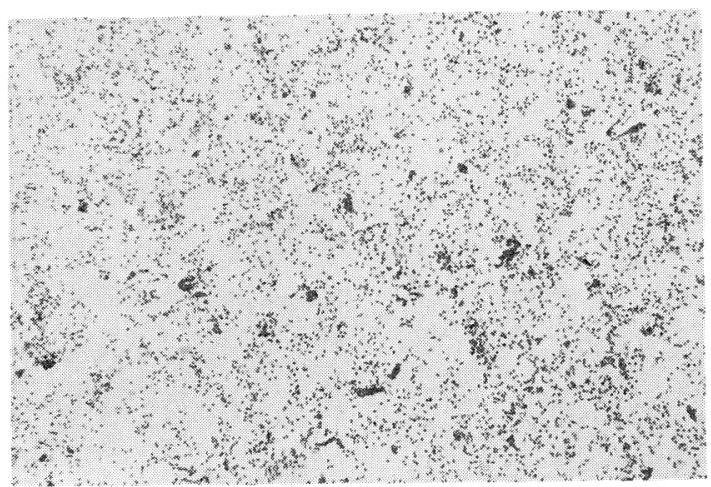

図 3 細胞分散度 “良” の標本

(耳下腺の腺样のう胞癌, Pap。染色, × 25)

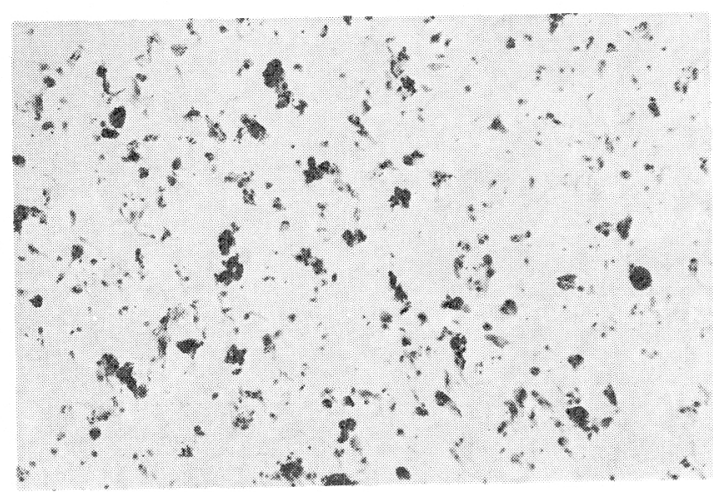

図 5 細胞分散度 “可” の標本

(肺の乳頭状腺癌, Pap. 染色, $\times 25$ )

一ボワックス・50\% エタ)ール液 (50\% エタノールに $2 \%$ の割にカーボワックス 1,540 を加えたもの)で固定 した。

2. 方 法

攪拌時間の検討

(1) 剖検により得られた腺癌組織を細切したものを

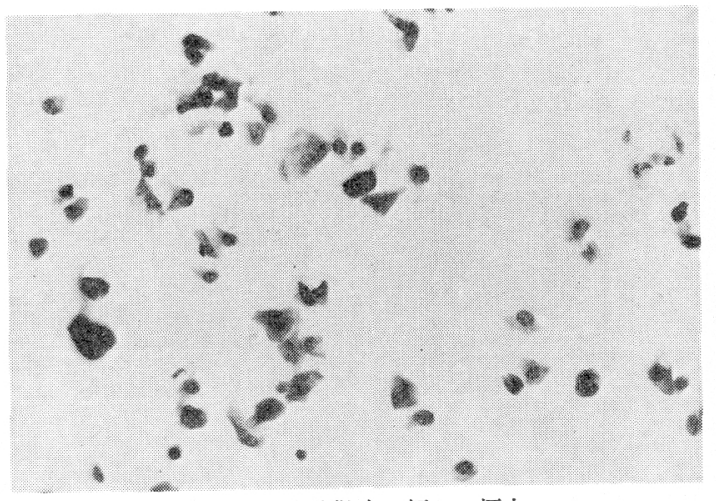

図 2 細胞分散度 “優” の標本

(乳腺の充実腺管癌, Pap. 染色, ×100)

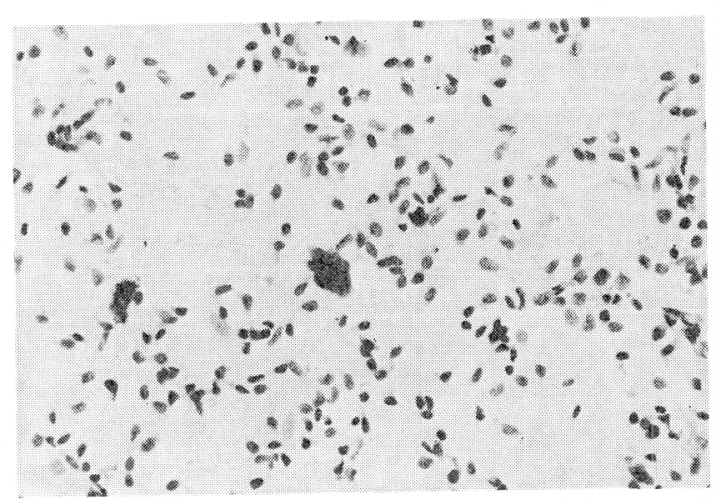

図 4 細胞分散度“良”の標本

(耳下腺の腺様のら胞癌, Pap. 染色, $\times 100$ )

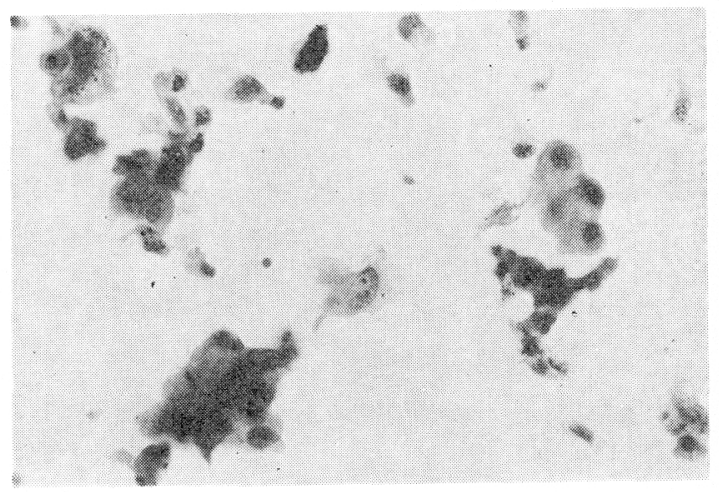

図 6 細胞分散度 “可” の標本 (肺の乳頭状腺湂, Pap. 染色, $\times 100$ )

$2 \%$ カーボワックス・ $50 \%$ エタノール液に大れ，これを 高速ブレンダーで $5,10,20,30,45$ 秒， 1, 3, 5, 7 および 10 分間攪汼した $(21,000 \mathrm{rpm})$.

(2) $2 \%$ カーボワックス・ $50 \%$ エタノール液約 $10 \mathrm{ml}$ に適量の攪汼物の上清を入れた。

(3) これをオートスミアにより $14 \times 30 \mathrm{~mm}$ の範囲に 
表 1 組織亜型と分散度

\begin{tabular}{|c|c|c|c|c|}
\hline 分散度 ${ }^{\text {組織晋型 }}$ & 乳頭状癌 & 非乳頭状癌 & 硬＼cjkstart癌 & \\
\hline 優 & $4(36 \%)$ & $31(76 \%)$ & $2(67 \%)$ & 37 例 \\
\hline 良 & $5(46 \%)$ & $5(12 \%)$ & $1(33 \%)$ & 11 例 \\
\hline \multirow[t]{2}{*}{ 可 } & $2(18 \%)$ & $5(12 \%)$ & - & 7 例 \\
\hline & 11 例 & 41 例 & 3 例 & 55 例 \\
\hline
\end{tabular}

表 2 細胞分化度と分散度

\begin{tabular}{c|c|r|r|r}
\hline \multirow{2}{*}{$\begin{array}{c}\text { 分散度 } \\
\text { 細胞分化度 }\end{array}$} & 高 & 中 & 低 & \\
\hline 優 & $9(53 \%)$ & $14(64 \%)$ & $14(88 \%)$ & 37 例 \\
良 & $3(18 \%)$ & $6(27 \%)$ & $2(12 \%)$ & 11 例 \\
可 & $5(29 \%)$ & $2(9 \%)$ & - & 7 例 \\
\hline & 17 例 & 22 例 & 16 例 & 55 例 \\
\hline
\end{tabular}

塗抹した $(1,500 \mathrm{rpm}, 5$ 分).

攪汼時間の長いものほど一般に細胞分散は良好であっ たが, 症例によってさほど変わらないものもあった. 5 秒間の靦拌でも分散良好な症例もあり, 10 分間の覮挥で もなお, 細胞集塊が残存している症例もあった. 細胞の 分散と保存の両観点より覺汼時間を 1 分とし, 粗大な細 胞集塊, ごみなどはメッシュで除き, 次のような分散法 を確立した。

(1) 材料を $2 \%$ カーボワックス・ $50 \%$ エ夕ノール液に 入れ高速ブレンダーで 1 分間攪挥する. 剖検および手術 材料では攪汼物をさらに乳鉢で粉砕し再攪找する.

(2) あらかじめ $2 \%$ カーボワックス・ $50 \%$ エタノール 液 $10 \mathrm{~m} l$ を入れてある試験管に適量の上清を入れる.

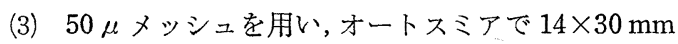
の範囲に塗抹する (1,500 rpm, 5 分).

細胞分散度を癌の組織構造と癌細胞の分化度より検討 した.

細胞の分散度を優, 良, 可に分けた. 優とは癌細胞集 塊の $80 \%$ 以上が 5 個以下の核より構成されているもの (図 1,2), 良とは 10 個以下のもの(図 3,4 ), 可とは 11 個以上のもの(図 5,6 ) と定義した.

細胞質の保存を優, 良, 可に分けた. 優とは過半数 （80\%以上）の癌細胞の細胞質が保存されているもの， 良とは半数 $(50 \%)$ 程度の細胞質が保存されているもの, 可とは細胞質が失われほとんど裸核のものと定義した.

腺癌の組織要型を乳頭状, 非乳頭状 (充実性, 䯣様, 髄様腺管状) および硬癌（びまん性増殖）に分けた。

癌細胞の分化度を高分化, 中等度分化, 低分化に分け た. 高分化とは癌細胞の大きさ, 形がほぼ揃い, 核・細
胞質比の比較的小さいもの, 低分化とは癌細胞の大き さ, 形が不揃いで核・細胞質比の大きいもの，あるいは 裸核状で散在性に出現するもの, 中等度分化とは両者の 中間のものと定義した。

\section{3. 成 績}

上記 58 例中, 分散標本に癌細胞の少数のもの, 組織所 見と対比し得なかった 3 例を除く 55 例についての成績 は, 表 1,2 のようになった. 非乳頭状癌は乳頭状癌より も分散は良好であった。 また，分化の低い癌ほど分散は 良好であった，細胞質の保存については優のもの 46 例 (84\%)，良のもの 7 例 (13\%), 可のもの 2 例 (3\%) と なった. 高速度の攪拌にもかかわらず細胞質の損失は意 外に少なかった。

\section{III. streptolysin-0 による好中球除去法}

好中球を除去するために選択的にこれを融解する streptolysin-O の効果を検討した.

\section{1. 材料および方法}

（1）子宮胵部擦過綿球を ASLO 価測定用食塩水に入 れ，綿球に付着した細胞を用手的にしぼり出す.

(2) これを高速ブレンダーで攪䢁 $(21,000 \mathrm{rpm}, 5$ 秒) 後, 遠沈する (1,500 rpm, 5 分).

(3) この沈渣をあらかじめ streptolysin-O “栄研” (14 結合力価）を $1 \mathrm{~m} l$ の蒸溜水にとかしてある遠心管に入 れる.

(4) $37^{\circ} \mathrm{C}, 15$ 分閒反応後, 遠沈する $(3,000 \sim 3,500$ $\mathrm{rpm}, 5$ 分).

（5）この沈渣を生食水で洗浄して再び遠沈する $(1,500$ 


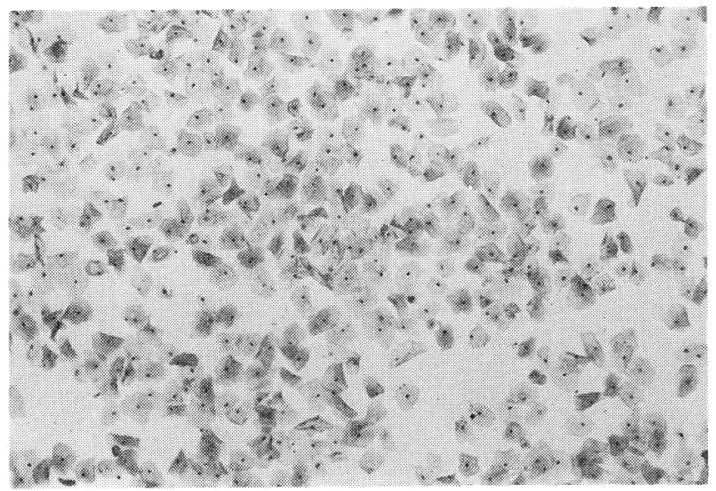

図 7 streptolysin-O の著效標本

好中球はほとんど消失している（Pap. 染色，×25）

rpm, 5 分).

（6）この沈渣に食塩水 $10 \mathrm{~m} l$ 少加光，高速ブレンダー で再摱䢁する $(21,000 \mathrm{rpm}, 3$ 秒 $)$.

(7) この液に $4 \%$ カーボワックス・ $95 \%$ エタノール液 (95\% エタノールに4\%の割にカーボワックス1,540を 加えたもの）を等量加えて固定する。

（8）オートスミアで塗抹 (メッシュは用いず), 乾燥 後, $95 \%$ エタノールで再固定し, 自動染色機で Papanicolaou 染色をする.

対照として, 高速ブレンダーで攪拌後, 薑沈した沈渣 をあらかじめ $1 \mathrm{~m} l$ の蒸溜水を入れてある遠心管に入れ る.これを $37^{\circ} \mathrm{C}, 15$ 分間放置後, 遠沈する. この沈渣を $2 \%$ カーボワックス・50\% エタノール液で固定し(8)の操 作に移る。

\section{2. 成 績}

腟スミアに好中球の多い 29 症例について検討した結 果，対照に比して有効と認められたものは 23 例 $(80 \%)$ 㐫り，そのうち，㷉平上皮細胞が主体を占め，好中球を 活とんど含まないもの (著效例) (図 7，8）は 14 例で無 效のものは 6 例 $(20 \%)$ となった。

\section{IV. 考察}

腺癌は概して扁平上皮癌より細胞集塊をつくりやす く, 細胞結合が緊密である. 画像処理方式による自動細 胞診では, 細胞集塊を遊離細胞に分散して判別する方法 と集塊そのもの判別する方法がある。後者の場合には 判別論理がより複雑となる。フロー方式による場合に は，細胞集塊はすべて遊離細胞に分散することが大前提 である。

腺癌の組織亜型, 細胞分化度と細胞分散の難易を検索 した報告はきわめて少ない。

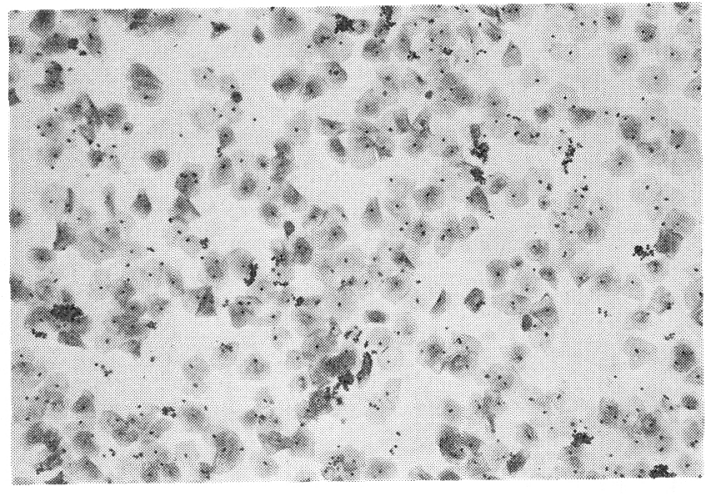

图 8 その対照 (反応前)

多数の好中球集塊がみられる (Pap. 染色，×25)

今回のわれわれの成績では組織構造からみると乳頭状 腺癌が, また細胞分化よりみると高分化腺癌の分散が最 も困難であった。これ腺癌でほ高分化のもの注ど細胞 集塊堂つくる傾向为強く, 細胞結合が腺癌の分化度を知 るひとつの手掛りとして用いられていることに符合す る.

フロー方式で恬癌特異抗原に詨する標識単クローン抗 体を用いて, 癌細胞のスクリーニングを行うので, 細胞 質が失われない前処理法でなければならない。われわれ の方法では高速で 1 分間覮拌したが，この点はまず満足 される成績とみてよいであるう。

自動細胞診を目的とした腺癌細胞の分散法については Lopez $ら^{2)}$ 注子宫癌, 卵巣癌などの腺癌細胞を syringing により分散し，その難易度をあらわす指数として分 散指数を設定し, syringing 圧と分散指数との関係を検 索した. 腺癌は扁平上皮癌上りも分散指数が大きく, 大 きい細胞集塊は syringing 圧をたかめても分散できない ものが多いと述へている。

好中球はフロー方式では判定に支障をきたさないが， 画像処理方式では扁平上皮細胞と重積したり, あるいは 好中球集塊そのものが誤陽性の原因になり，これを除去 する必要がある.

前回 ${ }^{4)}$ われわれは Separate-L を腔スミアに好中球の 多い26症例に用いて検討したところ, 16 例 $(62 \%)$ に有 効であった。 しかし，本法は操作が煩雑で癌細胞が前処 理過程で失わ礼る打それがある。この点老考慮すると streptolysin-O による方が優れているともいえよう.

Rosenthal ら ${ }^{3)} 10 \mu$ のナイロン製メッシュを用い て，好中球を上皮性細胞より分離している.

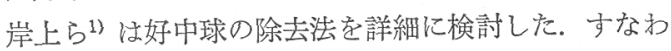
ち, 一層または多層の ficoll 液上に smear suspension を重層し，遠心㧍よび静置沈測法を試みた結果，比重 
1.024 の ficoll 液上に等量の smear suspension を重層 し, 30 分閒静置後, 下層の細胞を全部回収する一層静置 沈澱法が最も有効であったと述べている.

以上，われわれの基礎実験を集検に適用する場合，子 宮癌では体癌, 頸部腺癌, 肺癌では肺門型腺癌が対象と なる．われわれの細胞分散法はさほど経費を要せず，操 作は簡単であり, streptolysin-O による好中球除去法も 多少, 操作の煩雑な面はあるが, Separate-L よりも簡単 で経費も少なく，集検の実施に際して不可能な方法とは 思われない.

稿を終えるにあたり，ご協力頂いた当院婦人科医長・笠松達 弘博士, 当研究所病理部長・下里幸雄博士に媣謝いたします.

本研究は “厚生省対がん 10 力年総合戦略研究費”によった。

\section{Summary}

Considering the existence of adenocarcinoma in the mass screening for uterine cancer, we have modified the previous procedure and applied it to 55 adenocarcinomas to obtain well dispersed cell samples.

According to histological types, adenocarcinoma was classified into papillary, non-papillary and scirrhous ones and degree of cell dispersion was evaluated. Well dispersed cell samples were obtained from four of 11 papillary-, 31 of 41 non-papillary-, and two of three scirrhous carcinomas. Papillary carcinoma was the most difficult to produce a monolayer of isolated cells. According to cellular differentiation, adeno- carcinoma was classified into well, moderately and poorly differentiated ones. Well dispersed cell samples were obtained from 9 of 17 well-, 14 of 22 moderately-, and 14 of 16 poorly differentiated carcinomas. It was thought that the more cancer cells are differentiated, the more difficult they are to disperse. Though high speed blending was used in this procedure, 46 carcinomas ( $84 \%$ ) retained well preserved cytoplasm.

In order to eliminate polymorphonuclear leukocytes from vaginal specimens, which often lead to an erroneous diagnosis of non-cancer cells, streptolysin- $O$ was used to 29 vaginal samples containing a large number of polymorphonuclear leukocytes and was considered to be effective for 23 samples $(80 \%)$.

\section{文献}

1）岸上義彦・他 : 自動 screening に適した腟 smear の作製 法一特に子宮頸癌例について, 日 臨細胞誌, $22: 1 \sim 8$, 1983.

2) Lopez, P.A., et al. : Syringing as a method of cell dispersal II. Effect on abnormal cells, Anal. Quant. Cytol., $3: 235 \sim 238,1981$.

3) Rosenthal, D.L., et al. : A simple method of producing a monolayer of cervical cells for digital image processing, Anal. Quant. Cytol., $1: 84 \sim 88,1979$.

4）塩沢勇治・他 : 子宮癌細胞診自動化のための検体前処理法 の検討, 日臨細胞誌, $18: 120 \sim 126,1979$. 